failed to find any minerals of economic value, the investigations by Dr. N. R. Junner while director from 1928 onwards revealed high-grade iron ore, industrial diamond deposits, chromite, ilmenite and alluvial gold. Of these the first two mentioned have now reached major importance, more than 11,000,000 tons of hæmatite and $10,000,000$ carats of diamonds having been exported during 1930-49.

Sierra Leone is mainly underlain by rocks of FreCambrian age, of which approximately half the total area is granite. This is intrusive into metamorphic rocks, the schists, gneisses and granulites of the Kasila Series, the Kambui Schists and the Marampa Schists. The granite is overlain by folded unfossiliferous sediments, the Rokell River Series, and these in their turn are covered unconformably with bedded arenaceous rocks believed to be equivalent to Grès Horizonteaux of French Guinea, where fossil evidence indicates a Middle Silurian age. The primary iron-ore deposits consist of schistose specular hæmatite in the Marampa Schists, and banded iron-formation in the Kambui Schists. Near the surface, intense lateritic weathering has produced dense secondary hæmatite. The Colony peninsula is underlain by a banded noritic complex, including troctolite and gabbros, apparently lopolithic in form, and having other features in common with the great Bushveld lopolith in South Africa, including the presence of platinum.

Maps showing the geology and distribution of mineral localities on a scale of $1: 1,000,000$ accompany Mr. Pollett's article. Surveying of the Colony on the 1 inch : 1 mile scale has now begun with the expanded staff made possible by a grant from the Colonial Development and Welfare Scheme.

Under "Notes and Abstracts" an account is given of one of the first results of the recent effort to interest home university geological workers in Great Britain in problems of Colonial geology. A visit by Drs. J. Sutton and Janet Watson to Tanganyika to examine the granites and basement rocks is described in some detail ; Prof. W. Q. Kennedy visited Uganda.

The issue also includes articles on British Somaliland and on photogeology, and a laboratory report on glass sand from Nigeria. Reports from the various Geological Survey units indicate that geological work of considerable scientific interest as well as economic value is in progress in many parts of British Colonial territories.

K. C. DUNham

\section{PALATABILITY OF BIRDS' EGGS}

IN a paper submitted to the Zoological Society of 1 London (Proc. Zool. Soc. Lond., 121, Part I), Dr. Hugh Cott describes the results of an investigation into the relative acceptability of the eggs of twenty-five species of birds, belonging to ten orders, as illustrated by the feeding preferences of the hedgehog (Erinaceus europceus). In each of 332 experiments, one of four animals used as tasters was presented with a choice between two egg-samples. Possible disturbing factors such as differences in egg-size or shellcoloration, and those due to spatial arrangements of the samples, were eliminated by the use of raw egg, offered in equal quantities, and by the successive reversal in position of the egg-species matched within a particular group of experiments. or as offered to a particular experimental animal.

The reliability of the experimental method and the degree of consistency of hedgehog discrimination was checked by repetition experiments (between the same species-pair), both for the same and for different individuals ; and by linking and overlapping experiments (between pairs of egg-species more or less widely separated in the edibility series). In general, the results show the hedgehog to be sensitive to differences in the relative palatability of the eggs offered, and to be consistent in its preferences and aversions; these show a broad agreement with those of man for the egg-species considered.

The experiments, which fall into groups carried out with sixty species-pairs, afford a basis for the arrange. ment of the several species in a provisional hierarchy of preference. The species fall broadly into three grades, and in descending order of acceptability are as follows : (a) palatable-kittiwake, eider, razorbill, gannet, domestic fowl, lapwing, common tern, coot; (b) intermediate-wood-pigeon, little owl, rook, puffin, magpie, jackdaw, hobby, kestrel, little grebe, buzzard, arctic tern, ringed plover ; (c) distastefulblackbird, chaffinch, sedge-warbler, whitethroat, linnet.

It is believed that the preferences shown by hedgehogs are likely to correspond with those of other eggeating animals, and that, within the limits of the series examined, they afford a satisfactory basis for consideration of the data in general terms. The wide range in specific edibility rating found to occur within certain orders suggests that relative acceptability may be largely independent of systematic status; however, the low mean edibility rating for passeriform species indicates a trend towards nauseousness within this order. No close or obvious connexion has been traced between relative acceptability of the egg and feeding habits of the parent; nor is the quality of the egg at all constantly related to that of the flesh in the species examined.

Yet the experimental results also point towards ccrrelations between relative acceptability and various other ecological factors likely to influence susceptibility to attack by predators. First, there is a broad direct relationship between palatability of the egg and size of the parent. Secondly, the distribution, in terms of acceptability, of species having colonial and solitary nesting habits, respectively, shows a marked tendency for eggs of the former to be more, and those of the latter to be less, palatable. Thirdly, consideration of egg-palatability in relation to nest-site indicates that eggs laid in open nests in moderate growth or low herbage may be relatively distasteful as com. pared with those laid in various other situations. Fourthly, a general correlation is shown to exist between coloration of the shell and palatability of its contents. Broadly, cryptic eggs tend to belong to the higher edibility grades and distinctively marked eggs to the lower edibility grades.

Cott has also assessed the several species in terms of relative vulnerability, account being taken of such factors as size, weapons of defence, powers of offence, availability of the clutch, general habits, sociability and coloration. A general inverse correlation is shown to exist between the degree of vulnerability and that of acceptability - the most palatable eggs being those laid by non-vulnerable species, the most nauseous by those that are (otherwise) highly vulnerable. It is suggested that the facts point towards an adaptive interpretation of distastefulness in eggs, considered as a deterrent to attack ; and that the distinctive coloration of nauseous, but otherwise vulnerable, eggs may have a warning or recognitional value in relation to potential predators. 